\title{
FRAMEWORK FOR VALUATION UNDER VARIABLE WACC
}

\author{
Uday Kumar Jagannathan ${ }^{1}$
}

DOI: https://doi.org/10.31410/ERAZ.2019.125

\begin{abstract}
The scope of this research is to provide a theoretical framework to the Variable Cost of Capital. Current theory uses Static Capital Structure and Constant Cost of Capital for Firm Valuation. This is being challenged and an improved approach to measure the Firm value on the basis of a Variable Capital Structure and hence Variable Cost of Capital, is being proposed. When a firm changes its Financial Leverage, it is expected that the Components of Cost of Capital will change. Cost of Equity is known to have a linear relation with Financial Leverage). If the level of Debt in Capital Structure varies, the cash flow available to the Debt holders as well as the Equity holders will change. The risk-level borne by the Debt holder as well as the Equity holder will also change. Keeping this in mind, the constancy assumption of the Cost of Debt is being challenged in the paper. The Weighted Average Cost of Capital, useful for discounting firm cash flows, is being estimated as being Variable with time, in the proposed paper. The existing and proposed Valuation Frameworks are being detailed below and the variables in the current literature as well as the proposed concept are tabulated below. This empirical investigation should be conducted with a set of sample firms. The results from the empirical investigation should be divided into Valuation using Static WACC and Valuation using Dynamic WACC. The difference in Value obtained using the two methodologies should be compared for statistical differences. The idea of Dynamic WACC can be extended to the problem of Firm Valuation as well as Project Valuation and Corporate finance practitioners can get a better sense of the risk level of the firm.
\end{abstract}

Keywords: Variable WACC, Financial Leverage, Valuation.

\section{INTRODUCTION}

$\mathrm{T}$ he varied forms of Capital used to finance organizations creates the motivation for researchers to arrive at various Capital Structure theories, according to Parsons and Titman 2009) [1]. In the existing valuation formulation, Damodaran (2006) [2] uses WACC which is constant and does not change for the future years or for the Terminal Year. Similar formulations can be found in Koller, Goedhart and Wessels (2008) [3] as well as Fernandez (2011) [4]. However, in the proposed valuation framework the WACC is variable and depends on Financial leverage. The main drawback in the assumption of Constant WACC is that it is usually not true. Little research exists on the Dynamic nature of WACC. The traditional view of Capital Structure states that firm Leverage has an impact on the Cost of Debt and Equity, however there is no quantification provided and the practitioner is not able to arrive at, let alone use the Dynamic WACC for project or firm valuation.

Existing Valuation Formulation (for the $\mathrm{i}^{\text {th }}$ firm)

$$
V_{i, E X I S T}=\sum_{t=1}^{T} \frac{C F_{i, t}}{\left(1+W A C C_{i}\right)^{t}}+\left(\frac{C F_{i, T+1}}{\left(1+W A C C_{i}\right)^{T} x\left(W A C C_{i}-g_{i_{T}}\right)}\right)
$$

Where $V_{i, E X I S T}$ is the current market value of the $\mathrm{i}^{\text {th }}$ firm, $C F_{i, t}$ is the cash flow of the $\mathrm{i}^{\text {th }}$ firm in time $t, W A C C_{i}$ is the Static WACC for the $\mathrm{i}^{\text {th }}$ firm across the time intervals. 


\section{PROBLEM STATEMENT}

Capital Structure cannot be constant in time, owing to the variable nature of Financial Leverage with time. In the Indian context, Financial Leverage is sticky with time Jagannathan and Suresh (2017), it is time-variant [5]. Cost of Equity varies with Financial Leverage according to Modigliani and Miller (1958) [6] the Cost of Equity $r_{E}$ is a function of the Leverage Ratio (D/E), $r_{o}$ is the unlevered cost of equity, $r_{D}$ is the cost of borrowings and $T_{C}$ is the Corporate Tax Rate.

$$
r_{E}=r_{0}+\frac{D}{E}\left(r_{0}-r_{D}\right)\left(1-T_{C}\right)
$$

If the Cost of Equity is variable and Financial Leverage while sticky, is not a constant year on year, it is clear that WACC cannot be a constant year on year.

\section{PROPOSED SOLUTION}

There is scant literature on the topic of Dynamic WACC. Contribution of Honková (2012) [7] has provided some insight into how a Dynamic WACC can be modelled, however there is no extension of the model to perform a Corporate Valuation with the obtained Dynamic WACC.

It is therefore being proposed that a Dynamic value of WACC be developed in the context of firm valuation. The Dynamic WACC will need three components for successful implementation. The first is the future Debt to Market Value Ratio as a function of time given by $(D / V)_{t}$. Since Capital Structure is sticky the value can be formulated as:

$$
\frac{D}{V}_{i, t}=\alpha_{i}+\sum_{j=1}^{p} \beta_{i, t-j} \frac{D}{V i, t-j}+\varepsilon_{i, t}
$$

Where $D / V_{i, t}$ is the Financial Leverage of the $\mathrm{i}^{\text {th }}$ firm in time $t$ and $p$ is the number of lags in the variable in years. The variable $\beta_{i, t-j}$ is the coefficient of the lag of the leverage ratio for the $j^{\text {th }}$ lag and the $i^{\text {th }}$ firm. $\varepsilon_{i, t}$ is the random term which is expected to have mean zero.

Further, it is hypothesized that the Cost of Debt and Equity will vary with firm Leverage as:

$$
\begin{aligned}
& k_{i, d t}=k_{i, d 0}+\phi_{i}\left(\frac{D}{V}\right)_{i . t}+\varepsilon_{i, t} \\
& k_{i, e t}=k_{i, e 0}+\pi_{i}\left(\frac{D}{V}\right)_{i, t}+\varepsilon_{i, t}
\end{aligned}
$$

Where $k_{i, d t}$ is the Cost of Debt in time $\mathrm{t}$ for the $\mathrm{i}^{\text {th }}$ firm, $k_{i, e t}$ is the Cost of Equity in time $\mathrm{t}$ for the $\mathrm{i}^{\text {th }}$ firm, $k_{i, d t 0}$ is the Cost of Debt for the $\mathrm{i}^{\text {th }}$ firm when there is zero Debt, $k_{i, e 0}$ is the Cost of Equity for the firm when there is zero Debt, $\phi_{i}$ and $\pi_{i}$ are coefficients related to the Leverage function predicted in Equation (3) above. Therefore, it is possible to predict the Dynamic WACC given in Eq. 6 below.

The Dynamic WACC is proposed as the following:

$$
W A C C_{i, t}=\left(\frac{D}{V}\right)_{i, t} \cdot k_{i, d}+\left(\frac{E}{V}\right)_{i, t} \cdot k_{i, e}
$$

The Proposed Valuation framework is as follows

$$
V_{i, P R O P O S E D}=\sum_{t=1}^{T} \frac{C F_{i, t}}{\left(1+W A C C_{i, t}\right)^{t}}+\left(\frac{C F_{i, T+1}}{\left(1+W A C C_{i, T}\right)^{T} x\left(W A C C_{i, T}-g_{i_{T}}\right)}\right)
$$


Table 3.1: Comparison of Existing vs. Proposed Frameworks for Estimation of Variable WACC

\begin{tabular}{|c|c|c|}
\hline S.No & $\begin{array}{l}\text { Existing Time-Invariant Variables } \\
\text { for the } \mathrm{i}^{\text {th }} \text { firm }\end{array}$ & $\begin{array}{l}\text { Proposed Time-Variant variables } \\
\text { for the } i^{\text {th }} \text { firm }\end{array}$ \\
\hline 1. & $\begin{array}{c}\text { WACC }=\left(\frac{D}{V}\right) \cdot(1-T) \cdot k_{d}+\left(\frac{E}{V}\right) \cdot k_{e}= \\
\text { Constant (time }- \text { Invariant })\end{array}$ & $\begin{array}{c}\text { WACC } C_{t}=\left(\frac{D}{V}\right)_{t} \cdot(1-T) \cdot k_{d t}+\left(\frac{E}{V}\right)_{t} \cdot k_{e t} \\
\text { Non-Constant (time-Variant) }\end{array}$ \\
\hline 2. & $\begin{array}{c}k_{d}=\text { Constant }(\text { time }- \text { Invariant }) \\
k_{d}=\text { Interest_paid }_{t=0} / \text { Total_Debt } \text { Int }_{t=0}\end{array}$ & $\begin{array}{l}\qquad k_{d t}=k_{d 0}\left(1+\alpha_{1}\left(\frac{D}{V}\right)_{t}\right) \\
\text { The value of kd will be calculated for each future } \\
\text { time period (year) as a function of }(D / V)_{t}\end{array}$ \\
\hline 3. & $\begin{array}{c}k_{e}=\text { Constant (time }- \text { Invariant) } \\
k_{e}=R_{f}+\beta_{i}\left(R_{m}-R_{f}\right) \\
\text { Existing literature uses the CAPM and } \\
\text { assumes the value at present time and holds it } \\
\text { for period of valuation }\end{array}$ & $\begin{array}{l}\qquad k_{e t}=k_{e 0}\left(1+\alpha_{2}\left(\frac{D}{V}\right)_{t}\right) \\
\text { The value of ke will be calculated for each future } \\
\text { time period (year) as a function of }(D / V)_{t}\end{array}$ \\
\hline 4. & $\frac{D}{V}=$ Constant $($ time - Invariant $)$ & $\left(\frac{D}{V}\right)_{t}=$ Variable as stated in Eq. 3 above \\
\hline 5. & $\begin{array}{l}\text { Value is calculated with the help of static } \\
\text { WACC using Formula for } V_{E X I S T}\end{array}$ & $\begin{array}{l}\text { Value is calculated with the help of Dynamic } \\
\text { WACC using the formula for } V_{P R O P O S E D}\end{array}$ \\
\hline
\end{tabular}

\subsection{Intended Theoretical Contribution}

1. Estimation of difference between Value obtained from Static WACC and Market Value call this $\Delta V_{i, E X I S T}$

2. Estimation of difference between Value Obtained from Dynamic WACC and Market Value call this $\triangle V_{i, P R O P O S E D}$

3. Analysis of whether result obtained from 1 is statistically different from 2 (t-test of difference in means between mean of $\Delta V_{i, E X I S T}$ and mean of $\Delta V_{i, P R O P O S E D}$

Table 2.2: Possible Outcomes of the Research

\begin{tabular}{|l|l|l|}
\hline S.No & Research Outcome & Research Implication \\
\hline 1. & $\begin{array}{l}\text { No Statistical Difference between } \Delta V_{i, E X I S T} \text { and } \\
\Delta V_{i, P R O P O S E D}\end{array}$ & $\begin{array}{l}\text { No change in Theory, because Static WACC is } \\
\text { easier to estimate }\end{array}$ \\
\hline 2. & $\begin{array}{l}\text { Statistical Difference between } \Delta V_{i, E X I S T} \text { and } \\
\Delta V_{i, P R O P O S E D} \text { and } \Delta V_{i, E X I S T} \text { is superior }\end{array}$ & No change in Theory \\
\hline 3. & $\begin{array}{l}\text { Statistical Difference between } \Delta V_{i, E X I S T} \text { and } \\
\Delta V_{i, P R O P O S E D} \text { and } \triangle V_{i, P R O P O S E D} \text { is superior }\end{array}$ & $\begin{array}{l}\text { Change in Theory, and it is better to use Dynamic } \\
\text { WACC }\end{array}$ \\
\hline
\end{tabular}

Table 3: A possible Empirical Approach to Test the theory

\begin{tabular}{|l|l|l|}
\hline S.No & Empirical Approach & Intended Result \\
\hline 1. & $\begin{array}{l}\text { Using a Sample of Firms, Fixed-Effect Regression } \\
\text { to isolate Coefficients for Eq. } 3 \text { above. }\end{array}$ & $\begin{array}{l}\text { The Value of }(D / V)_{i, t} \text { is isolated as a function } \\
\text { of Dependent Variables in so that the future } \\
\text { Leverage Ratio can be estimated. }\end{array}$ \\
\hline 2. & $\begin{array}{l}\text { Using a Sample Firms, Fixed-Effect Regression to } \\
\text { Isolate Coefficients for } k_{i, d t} \text { given the Eq } 4 \text { above. }\end{array}$ & $\begin{array}{l}\text { The value of } k_{i, d t} \text { is obtained as a function of } \\
(D / V)_{t} \text { or the Time-Variant } D / V . \text { The value of the } \\
\text { intercept obtained is the value of } k_{d 0}\end{array}$ \\
\hline 3. & $\begin{array}{l}\text { Using a Sample of Firms, Fixed-Effect Regression } \\
\text { to Isolate Coefficients for } k_{i, e t} \text { given the Eq } 5 \\
\text { above. }\end{array}$ & $\begin{array}{l}\text { The value of } k_{i, e t} \text { is obtained as a function of } \\
(D / V) t \text { or the Time-Variant } D / V \text {. The value of the } \\
\text { intercept obtained is the value of } k_{e 0}\end{array}$ \\
\hline 4. & $\begin{array}{l}\text { Calculations of } V_{i, E X I S T}, V_{i, P R O P O S E D} \text { and } \Delta V_{i, E X I S T} \text { and } \\
\Delta V_{i, P R O P O S E D} \text { are made on the basis of Static and } \\
\text { Dynamic WACC respectively. }\end{array}$ & $\begin{array}{l}\text { The empirical investigation will give Calculated } \\
\text { Values of the firm based on the Static and } \\
\text { Dynamic WACC }\end{array}$ \\
\hline 4. & $\begin{array}{l}\text { Sample and a t-test for the difference in Sample } \\
\text { means between } \Delta V_{i, E X I S T} \text { and } \Delta V_{i, P R O P O S E D} \text { is } \\
\text { performed }\end{array}$ & $\begin{array}{l}\text { The results of the t-test will reveal whether there } \\
\text { is any difference between } V_{i, E X I S T} \text { and } V_{i, P R O P O S E D}\end{array}$ \\
\hline
\end{tabular}




\subsection{Research Implications}

The prediction of $\mathrm{D} / \mathrm{V}$ Ratio for future periods can help the practitioner determine the risk level of the firm in future years. The risk level is increased if the leverage is increased and this is found in increase of both the Cost of Debt as well as Cost of Equity, when leverage is increased. The linkage between D/V and the Cost of Debt and Equity can be together used to formulate a Dynamic (as opposed to Static) WACC and this could give a better result on the Valuation, as should be considered by practitioners in Corporate Finance.

\subsection{Research Limitations and Scope for Future Research}

The research has focused on obtaining the $\mathrm{D} / \mathrm{V}$ value for the future and has been able to do so. The assumptions made in the chapter could be construed as limitations. Only five years are proposed into the future for projecting the Cash flows, in most current literature. It could be argued that the firm need not reach the Terminal Cash flow levels in five years. It could also be argued that since Dynamic WACC is being proposed in the calculation, how could the Terminal Value of the Dynamic WACC be a constant? Are lag variables sufficient in estimation of $(\mathrm{D} / \mathrm{V})_{\mathrm{t}}$ or are there other variables that can further improve the accuracy level of the prediction of $(D / V)_{t}$ ?

\section{REFERENCES}

[1] Parsons, C A. and Titman, S, Empirical Capital Structure: A Review (2008). Foundations and Trends in Finance, Vol. 3, No. 1, pp. 1-93, 2008. Available at SSRN: https://ssrn.com/ abstract $=2131759$

[2] Damodaran, Aswath (2006) Damodaran on Valuation: Security Analysis for Investment and Corporate Finance (Wiley Finance)

[3] Koller Tim, Goedhart Marc and Wessels, David (2008) Valuation, Measuring and Managing the Value of Companies, Wiley, $4^{\text {th }}$ edition

[4] Fernandez, Pablo, Company Valuation Methods (October 11, 2017). Available at SSRN: https://ssrn.com/abstract=274973 or http://dx.doi.org/10.2139/ssrn.274973

[5] Jagannathan, Uday Kumar; Suresh, N. The Nature and Determinants of Capital Structure in Indian Service Firms. Indian Journal of Finance, [S.1.], p. 30-43, Nov. 2017. ISSN 0973-8711. Available at: <http://www.indianjournaloffinance.co.in/index.php/IJF/article/ view/119340>. Date accessed: 10 May. 2019. Doi:10.17010/ijf/2017/v11i11/119340.

[6] Modigliani, F., \& Miller, M. H. (1958) The cost of capital, corporation finance and the theory of investment, The American economic review, 261-297.

[7] Honková, I., (2012). Dynamic model WACC. In: Advances in Finance \& Accounting: Proceedings of the 1st WSEAS International Conference on Finance, Accounting and Auditing, Zlín: Tomas Bata University, 268-274 